\title{
PENANGANAN TINDAK PIDANA PEMBUNUHAN YANG DILAKUKAN OLEH ANAK BERDASARKAN RESTORATIVE JUSTICE
}

\author{
Chandra Noviardy Irawan \\ Fakultas Hukum Universitas Diponegoro, Semarang \\ chandranoviardyirawan@yahoo.com
}

\begin{abstract}
Abstrak
Tujuan penelitian ini adalah untuk memberikan gambaran dan menganalisis seperti apa penanganan pembunuhan yang dilakukan oleh anak dengan pendekatan restorative justice. Penanganan perkara anak yang melakukan. tindak pidana harus dibedakan dari penanganan pada kasus dewasa, termasuk anak dengan tindak pidana pembunuhan, yang pada proses penanganannya mendapatkan tekanan terutama saat proses pemeriksaan perkara sedang berlangsung yang akan memberikan pengaruh pada sikap mental anak, pelaksanaan penanganan perkara pidana pembunuhan oleh anak memiliki ciri khas tertentu yang ditujukan untuk melindungi anak tersebut, penelitian ini ditujukan untuk mengupas bagaimana tindak pidana tersebut ditangani dengan memperhatikan perlindungan terhadap anak. Metode penelitian yuridis normatif dilaksanakan dengan pendekatan undang-undang. Hasil penelitian ditemukan bahwa sistem peradilan anak pendekatan yang dikenal dengan diversi diberikan kepada anak yang masuk dalam kategori anak dengan kenakalan atau anak yang melakukan. Tindak pidana pembunuhan dalam penjatuhan pidana terdapat perbedaan. Penjatuhan pidana pembunuhan terhadap anak berupa pidana pokok lebih bersifat peringatan yaitu pidana ringan yang tidak menimbulkan pembatasan pada kebebasan yang dimiliki oleh anak, dan bersifat syarat meliputi pembinaan di luar ataupun di dalam lembaga; pelayanan pada masyarakat; pengawasan; pelatihan kerja; \& penjara sebagai upaya terakhir. Oleh karenanya dapat disimpulkan bahwa penanganan anak sebagai pelaku tindak pidana pembunuhan di masa yang akan datang perlu disesuaikan dengan prinsip restorative justice.
\end{abstract}

Kata Kunci : Anak; Penanganan; Pembunuhan; Restorative Justice

\section{HANDLING THE CRIME OF MURDER PERPETRATED BY CHILDREN THROUGH RESTORATIVE JUSTICE}

\begin{abstract}
The purpose of this study is to provide an overview and analyze how the handling of murders committed by children with a restorative justice approach is like. The handling of cases of children who commit crimes must be distinguished from the handling of adults, including children who commit crimes of murder. the process of handling this specific case causes pressure to the children, especially in the examination process, which will give effect to the mental attitude of children. The implementation of handling criminal cases of murder. by children who have specific characteristics that are intended to protect the child, this study aims to explore how these crimes are handled by paying attention to the protection of children. The research method used is normative juridical research utilizing the statute approach. lt was found that the juvenile justice system approach known as diversion is given to children who fall into the category of naughty children or children who commit the crime of murder in criminal convictions; there are differences. The imposition of the crime of murder against a child in the form of a principal punishment is more of a warning nature, namely a light sentence that does not limit child's freedom, and has the following conditions: coaching outside or inside the institution; service to the community; supervision; job training; and imprisonment as a last resort. Therefore, it can be concluded that the handling of children as perpetrators of murder crimes in the future needs to be adjusted to the principles of restorative justice.
\end{abstract}

Keywords: Children; Handling; Murder; Restorative Justice 


\section{A. PENDAHULUAN}

Anak merupakan penerus bangsa yang memiliki tanggungjawab untuk melanggengkan kesejahteraan di masa mendatang. ${ }^{1}$ Dengan landasan pemikiran yang demikian maka perlu adanya perlindungan terhadap anak agar di masa yang akan datang anak memiliki kemampuan serta kesiapan dalam memikul tanggung jawab yang beritu berat. ${ }^{2}$ Perlakuan yang dimaksud termasuk perlindungan pengupayaan kesejahteraan anak yang memperhatikan hak-hak anak sebagai manusia tanpa adanya diskriminasi dalam aspek apapun. ${ }^{3}$ Perlindungan anak yang dihadapkan kepada permasalahan hukum secara predominan merujuk kepada Undang-Undang Nomor 11 Tahun 2012 tentang Sistem Peradilan Anak. ${ }^{4}$ Selain itu tujuan atas perlindungan anak yang diberikan termanifestasi dalam Pasal 3 Undang-Undang Nomor 35 Tahun 2014 tentang Perlindungan Anak yaitu untuk memberikan jaminan terhadap keterpenuhan hak-hak anak untuk hidup, bertumbuh dan berkembang, serta melibatkan dirinya dengan maksimal dengan memperhatikan harkat-martabat

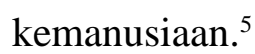

Tidak jarang anak memiliki perilaku yang menyimpang dalam perspektif hukum dengan melakukan perbuatan-perbuatan yang ditentukan dilarang oleh hukum. ${ }^{6}$ Hal ini dapat ditimbulkan oleh berbagai faktor seperti pengaruh negatif dari luar anak yang timbul akibat pembangunan dengan tempo cepat, pengaruh globalisasi dalam aspek teknologi komunikasi dan indormasi. ${ }^{7}$ Sehingga sebagai hasil atas absennya pendampingan tersebut memberikan pengaruh terhadap perubahan sosial yang fundamen dalam nilai dan perilaku anak. ${ }^{8}$ Mekanisme pertahanan diri terhadap pengaruh negatif yang terderivasi dari perkembangan jaman yang dapat berasal dari orang tua, wali, orang tua asuh ataupun pihak lain yang dapat berperan serta dalam hal perlindungan dan pembimbingan tersebut. ${ }^{9}$ Kenakalan yang dimaksud tersebut dikenal dengan "juvenile delinquency", ${ }^{10}$ selain itu dapat juga dimaknai sebagai tingkah laku menyalahi norma dalam kategori ringan dan tingkah

\footnotetext{
${ }^{1}$ Muhammad Fachri Said, "Perlindungan Hukum Terhadap Anak Dalam Perspektif Hak Asasi Manusia," JCH (Jurnal Cendekia Hukum) 4, no. 1 (2018): 141, https://doi.org/10.33760/jch.v4i1.97.

${ }^{2}$ Ria Juliana dan Ridwan Arifin, "Anak dan Kejahatan (Faktor Penyebab dan Perlindungan Hukum)," Jurnal Selat 6, no. 2 (2019): 225-34, https://doi.org/10.31629/selat.v6i2.1019.

${ }^{3}$ Said, "Perlindungan Hukum Terhadap Anak Dalam Perspektif Hak Asasi Manusia."

${ }^{4}$ Anshari dan Nina Niken Lestari, "Efektivitas Penerapan Konsep Diversi dan restorative Justice dalam Sistem Peradilan PIdana Anak (Telaah Yuridis Empirik terhadap Kasus Delinkuensi Anak di Pengadilan Negeri Pontianak)," Res Judicata 4, no. 1 (2021): 99-118, https://doi.org/10.5040/9781509934904.ch-021.

5 Juliana dan Arifin, "Anak dan Kejahatan (Faktor Penyebab dan Perlindungan Hukum)."

${ }^{6}$ Dony Pribadi, "Perlindungan Terhadap Anak Berhadapan Dengan Hukum," Jurnal Hukum Volkgeist 3, no. 1 (2018): 15-28, https://doi.org/10.35326/volkgeist.v3i1.110.

7 Ana Puji Astuti, Anike Nurmalita, dan Rohma Fahlepi Doni, "Teknologi Komunikasi dan Perilaku Remaja," Jurnal Analisa Sosiologi 3, no. 1 (2014): 91-111.

${ }^{8}$ Laurensius Arliman S, "Perlindungan Hukum Bagi Anak Dalam Perspektif Pancasila Dan Bela Negara," UNIFIKASI : Jurnal Ilmu Hukum 05, no. 01 (2018): 58-70.

${ }^{9}$ Reza Fahlevi, “Aspek Hukum Perlindungan Anak Dalam Prespektif Hukum Nasional," Lex Jurnalica (Journal of Law) 12, no. 3 (2015): 177-91.

10 Juliana dan Arifin, "Anak dan Kejahatan (Faktor Penyebab dan Perlindungan Hukum)."
} 
laku yang melenceng. ${ }^{11}$ Delikeunsi sering juga di dikenal dengan kenakalan remaja yang dipadankan dengan kelainan dalam bertingkah laku, ataupun sebagai perbuatan/tindakan remaja. ${ }^{12}$ Remaja yang dimaksud dalam pembahasan ini merupakan anak yang berada pada 12 (usia dua belas) tahun dan 18 (delapan belas tahun) yang belum menikah. ${ }^{13}$

Anak dalam sistem hukum harus diberikan perlakuan khusus dan berbeda dengan orang dewasa karena, karena bila tidak, perlakuan yang sama tersebut dapat menempatkan anak kepada posisi yang merugikan kepada anak. ${ }^{14}$ Lebih khusus pada kasus anak yang melakukan tindak pidana pembunuhan, dalam proses ini anak tidak dapat dipungkiri menerima tekanan pada waktu pemeriksaan perkara yang tentu akan berpengaruh terhadap mentalitas anak. ${ }^{15}$ Dalam proses tersebut anak akan mengalami rasa takut, stres, yang selanjutnya mempengaruhi kreativitas dan kemampuan komunikasi anak. ${ }^{16}$ Salah satunya kasus anak yang berkaitan dengan tindak pidana pembunuhan. Kasus pembunuhan yang dilakukan oleh anak ini tentu akan mengganggu kenyamanan dan ketertiban di dalam masyarakat dan perlu mendapat perhatian khusus, hal ini dikarenakan (anak yang berhadapan dengan hukum) sebisa mungkin dihindarkan dari hukuman penjara. Melalui Undang-undang No. 11 Tahun 2012 Tentang Sistem Peradilan Pidana Anak (SPPA) aparat penegak hukum akan berusaha mencari solusi terbaik bagi sang anak.

Diversi akan diupayakan secara maksimal oleh pihak penyidik demi menghindarkan anak untuk masuk ke dalam SPP (Sistem Peradilan Pidana), karena akibat buruknya yang dapat diderita sang anak tersebut (anak yang berhadapan dengan hukum) apabila telah masuk dalam SPPA. Label pembunuhan akan diberikan oleh masyarakat kepada sang anak (anak yang berhadapan dengan hukum), dalam hal ini akan sangat mengganggu tumbuh kembang sang anak. Sistem peradilan pidana anak hadir guna sebagai pengejawantahan dari criminal justice system yang hakikatnya untuk penegakan sistem hukum pidana. ${ }^{17}$ Keadaan seperti yang digambarkan di atas akan sangat merugikan bagi kepentingan anak sebagai "subjek hukum" yang tentu akan sangat merugikan kepentingan anak. Jangan sampai nantinya setelah menjalani masa hukuman, anak menjadi bertambah kenakalannya. Hal tersebut dilakukan untuk menghindarkan anak yang pernah tersangkut perkara pidana dari hambatan untuk bersosialisasi dengan masyarakat, sehingga selanjutnya

${ }^{11}$ Violet Odala, “The Spectrum For Child Justice In The International Human Rights Framework: From 'Reclaiming The Delinquent Child' To Restorative Justice,” American University International Law Review 27, no. 3 (2012): 543-80.

12 Odala.

${ }^{13}$ S A Hasibuan, "Kebijakan Pertanggungjawaban Pidana Dalam Rangka Perlindungan Hukum Bagi Anak," Jurnal Hukum Responsif 7, no. 7 (2019): 169-75.

${ }_{14}$ Theresia Adelina dan A.A. Ngurah Yusa Darmadi, "Perlindungan Hukum Terhadap Anak Sebagai Pelaku Tindak Pidana Penganiayaan (Di Wilayah Hukum Kepolisian Resor Kota Denpasar)," Jurnal Hukum Pidana, (2017): 1-15.

${ }^{15}$ Andik Prasetyo, "Perlindungan Hukum Bagi Anak Pelaku Tindak Pidana," Mizan: Jurnal Ilmu Hukum 9, no. 1 (2020): 51, https://doi.org/10.32503/mizan.v9i1.1054.

16 Pribadi, "Perlindungan Terhadap Anak Berhadapan Dengan Hukum."

${ }^{17}$ Sitta Saraya, "Crime Of Public Information In Indonesia A Comparative Study Punishment System In Foreign Countries Thailand And Japan”, Jurnal Ius Constituendum 4,no. 2 (2019):130 
anak dapat mengabdikan diri kepada bangsa dan negara dan seluruh tumpah darahnya. ${ }^{18}$ Sehingga, dengan cara berpikir yang demikian, menangani perkara anak, terutama bagi para aparat penegak hukum diperlukan suatu bentuk perhatian khusus. Terutama pada proses pemeriksaan yang tidak dapat disamakan dengan pemeriksaan yang diberikan pada kasus orang dewasa. ${ }^{19}$

Diversi dinilai sebagai salah satu alternatif solusi atas permasalahan yang muncul dari kondisi di atas. Diversi adalah suatu tindakan/perlakuan yang dilakukan dalam tujuan untuk memindahkan penyelesaian suatu kasus dari penyelesaian secara formal ke arah penyelesaian secara non formal atau memberikan perlakuan berbeda pada pelaku tindak pidana anak dalam artian yang positif dengan menggunakan sistem peradilan anak atau menempatkan pelaku tindak pidana anak ke luar dari sistem peradilan pidana. ${ }^{20} \mathrm{Hal}$ ini diartikan bahwa tidak seluruh perkara kenalan anak/remaja harus diselesaikan melalui jalur formal berupa litigasi, dan memberikan jaminan atas ketersediaan penyelesaian alternatif berbasis keadilan restoratif (restorative justice) dengan mempertimbangkan kepentingan terbaik anak namun tidak mengabaikan aspek keadilan korban. ${ }^{21}$ Diversi dilakukan atas dasar alasan bahwa pelanggar hukum (offender) memiliki kesempatan untuk kembali menjadi manusia berbudi yang memiliki nilai dan norma yang sesuai dengan apa yang hidup di masyarakat melalui jalur non formal dengan pelibatan sumber daya dan peran masyarakat secara inklusif. Diversi sebagai alternatif dapat dimaknai sebagai upaya penegakkan keadilan terhadap anak yang telah melakukan tindak pidana.

Penelitian pertama, dilakukan oleh Hambali (2019) dan menemukan bahwa restorative justice sebagai alternatif penyelesaian dapat memberikan perlindungan terhadap anak, serta melalui penyelesaian tersebut anak tetap mempertanggungjawabkan pidananya tanpa dikurangi haknya sebagai anak. Kelebihan penelitian adalah menggunakan restorative justice sebagai bentuk pertanggungjawaban pidana terhadap anak, sedangkan kekurangannya tidak memperjelas pada tindak pidana apa saja yang boleh dilakukan restorative justice. ${ }^{22}$ Penelitian kedua, dilakukan oleh Nugraha dan Handoyo (2019), menemukan bahwa kepolisian Balikpapan dapat melakukan diskresi berupa diversi dalam penanganan tindak pidana Narkotika yang dilakukan oleh anak. Kelebihan dalam penelitian ini adalah memberi gambaran penanganan terhadap tindak pidana Narkotika yang dilakukan oleh anak. Kekurangannya adalah belum menggambarkan batasan-batasan

${ }^{18}$ Azwad Rachmat Hambali, "Penerapan Diversi Terhadap Anak Yang Berhadapan dengan Hukum Dalam Sistem Peradilan Pidana ( Diversions for Children in Conflict with The Laws in The Criminal Justice System )," Jurnal Ilmu Hukum 13 (2019): 15-30.

${ }^{19}$ Arliman S, "Perlindungan Hukum Bagi Anak Dalam Perspektif Pancasila Dan Bela Negara."

${ }^{20}$ Marlina, Peradilan Pidana Anak di Indonesia (Bandung: PT. Refika Aditama, 2009), 158.

${ }^{21}$ K D Pramatama dan K P Sudibya, "Pemidanaan Terhadap Anak Yang Melakukan Tindak Pidana Pembunuhan," Kertha Wicara: Journal Ilmu Hukum, (2019): 1-15.

${ }^{22}$ Hambali, "Penerapan Diversi Terhadap Anak Yang Berhadapan dengan Hukum Dalam Sistem Peradilan Pidana ( Diversions for Children in Conflict with The Laws in The Criminal Justice System )." 
tindak pidana narkotika yang seperti apa yang boleh dilakukan diversi, apakah seluruhnya ataukah ada hal-hal tertentu. ${ }^{23}$

Penelitian ketiga dilakukan oleh Ali (2019) menemukan bahwa pertanggungjawaban pidana terhadap anak yang melakukan pembunuhan adalah minimal di atas 12 tahun dan terdapat putusan hakim, serta stigma anak dalam melakukan tindak pidana pembunuhan bagi masyarakat sebagai sesuatu yang buruk dan menyimpang dari masyarakat. Kelebihan dari penelitian ini adalah menjelaskan pertanggungjawaban bagi anak sebagai pelaku tindak pidana pembunuhan. Kekurangannya adalah tidak dijelaskan penanganan anak dari setiap tingkatan, tindak pidana pembunuhan dalam KUHP, sanksi seperti yang dapat dijatuhkan terhadap anak, dan bagaimana menjaga anak agar tetap dapat perlindungan hukum. ${ }^{24}$

Berdasarkan penelitian terdahulu di atas berbeda dengan penelitian coba diangkat melalui tulisan ini, terdapat penekanan pada tindak pidana pembunuhan yang dilakukan oleh anak. Lebih lanjut apa yang diteliti oleh Ali sorotannya lebih kepada tinjauan yuridis atas pertanggungjawaban atas tindak pidana tersebut, dalam penelitian ini menyoroti tentang penanganan tindak pidana pembunuhan dengan pelaku adalah anak melalui sarana keadilan restoratif (restorative justice) dengan fokus kepada mekanisme penanganan tindak pidana tersebut. Hal ini dilakukan bertujuan untuk memberikan gambaran dan menganalisis seperti apa penanganan pembunuhan yang dilakukan oleh anak dengan pendekatan restorative justice.

\section{B. PERMASALAHAN}

Bertolak dari latar belakang permasalahan yang telah diuraikan di bagian pendahuluan, maka selanjutnya dapat dirumuskan dua rumusan masalah yaitu (1) Bagaimana penanganan pembunuhan menurut tindak pidana pada umumnya? (2) Bagaimana penanganan pembunuhan yang dilakukan anak berdasarkan restorative justice?

\section{METODE PENELITIAN}

Jenis penelitian doctrinal dipergunakan dalam penelitian ini, dimana upaya untuk menginventarisir hukum positif, asas-asas dan falsafah dalam hukum positif, serta penemuan atas hukum yang concreto. Data yang diperoleh dari proses literature collection dijabarkan di dalam hasil penelitian ini dengan perangkat analisis berupa teori-teori terkait pelaksanaan keadilan restoratif (restorative justice). Penjabaran data-data tersebut dilakukan secara deskriptif dengan judul penanganan tindak pidana pembunuhan dengan pelaku adalah anak melalui sarana keadilan restoratif (restorative justice). ${ }^{25}$

23 Windia Nugraha dan Susilo Handoyo, "Penerapan Restorative Justice dalam Penanganan dan Penyelesaian Tindak Pidana Narkotika yang Dilakukan oleh Anak di Kota Balikpapan," De Facto 6, no. 1 (2019): $1-20$.

24 Haidir Ali, "Pertanggungjawaban Tindak Pidana Pembunuhan Yang Dilakukan Oleh anak," Dinamika: Jurnal Ilmiah Hukum 5, no. 25, (2019): 1-7.

${ }^{25}$ Agus Riyanto, "The Existence and Legal Position of the Chief of Police Circular Regarding the Handling of Hate Speech", Journal of the Light of Justice 23, no. 2, (2012):3. 
Pendekatan dalam penelitian ini adalah pendekatan undang-undang dan konsep. Pendekatan yuridis yang dimaksud dalam penelitian ini berdasar kepada pendekatan normatif dalam upayanya untuk menemukan hukum yang memiliki sifat yang konkrit. ${ }^{26}$ Bahan hukum yang digunakan adalah bahan hukum primer yang berupa undang-undang serta bahan hukum sekunder berupa bahan kepustakaan dan dokumen-dokumen terkait. ${ }^{27}$ Telah disinggung sebelumnya berkaitan dengan alat analisis dalam penelitian ini yang merujuk pada perundang-undangan, asas-asas hukum, serta konsep-konsep pidana anak yang ada dengan cara memaparkan tentang bagaimana penanganan tindak pidana pembunuhan oleh anak menggunakan pendekatan keadilan restoratif (restorative justice) dilakukan.

\section{HASIL DAN PEMBAHASAN}

\section{Penanganan Pembunuhan Menurut Tindak Pidana secara Umum}

Istilah tindak pidana dari sisi kebahasaan berakar dari strafbaarfeit, meskipun begitu tidak ada penjelasan terkait dalam Kitab Undang-Undang Hukum Pidana (KUHP). Tindak pidana secara umumnya dipadankan dengan penggunaan kata delik dalam bahasa Latin disebut dengan delictum. Kamus hukum mencantumkan pembatasan delik yang didefinisikan sebagai delik perbuatan perbuatan yang dapat dikenakan hukuman atas dasar sebagai salah satu wujud pelanggaran terhadap undang-undang (tindak pidana). ${ }^{28}$ Strafbaarfeit atau tindak pidana sendiri terdiri dari tiga suku kata, pertama straf dengan arti pidana dan hukum, kedua baar yang artinya adalah dapat, dan ketiga feit yang diartikan sebagai pelanggaran dan perbuatan.

Moeljatno dalam tulisannya, menyebutkan bahwa hukum pidana merupakan elemen fundamental hukum sebagai dasar dan aturan yang dipergunakan untuk menentukan perbuatan-perbuatan yang tidak diperbolehkan untuk dilakukan yang merupakan larangan dengan ancaman sanksi atas suatu pidana tertentu untuk siapapun yang melakukan pelanggaran terhadap larangan tersebut dalam waktu serta kondisi yang menentukan seseorang yang melakukan pelanggaran terhadap laranganlarangan yang dimaksud dapat dijatuhi sanksi pidana seperti yang telah diatur dalam larangan tersebut, dan dengan cara apa pidana tersebut dapat dilaksanakan terhadap si pelanggar. ${ }^{29}$

Para ahli secara khusus tidak menjelaskan maksud ataupun defenisi atas pembunuhan, namun banyak yang mengkategorikan pembunuhan ke dalam kejahatan kepada nyawa (jiwa) orang lain. Kejahatan kepada nyawa (misdrijven tegen bet leven) merupakan penyerangan yang dilakukan kepada nyawa orang lain ataupun tindakan berbahaya terhadap nyawa orang lain. Sehingga melalui perspektif tersebut nyawa (leven) manusialah yang menjadi tujuan atas perlindungan hukum

${ }^{26}$ Dewi Rahmaningsih Nugroho, Muhammad Dzikirullah H. Noho,'Kajian Yuridis Kewenangan Pemerintah untuk Memerintahkan Melakukan Merger kepada Entitas Bank pada masa Wabah Covid19 dalam Rezim Perdagangan Internasional", Cakrawala Hukum 22, no.2, (2020): 17.

${ }^{27}$ Rizqi Purnama Puteri, Muhammad Junaidi dan Zaenal Arifin,”Reorientasi Sanksi Pidana Dalam Pertanggungjawaban Korporasi Di Indonesia”, Jurnal USM Law Review 3, no. 1 (2020):103

${ }^{28}$ Sudarsono, Kamus Hukum, (Jakarta: PT. Rineka Cipta, 2007), 92.

${ }^{29}$ Erdianto Effendi, Hukum Pidana Khusus Suatu Pengantar, (Bandung: PT. Refika Aditama, 2011), 67. 
yang akan diberikan. Kesengajaan yang menimbulkan hilangnya nyawa individu lain, di dalam Kitab Undang-Undang Hukum Pidana dinyatakan dengan terma pembunuhan yang secara khusus dinyatakan dalam Pasal 338 KUHP, dalam kaitannya sebagai perbuatan yang menimbulkan hilangnya nyawa individu lain tersebut, seorang pelaku melakukan sesuatu atau suatu rangkaian tindakan yang mengakibatkan meninggalnya orang lain dengan catatan bahwa opzet dari pelaku tersebut memiliki akibat yaitu meninggalnya/hilangnya nyawa individu lain. ${ }^{30}$

Tindak pidana terhadap nyawa sendiri secara khusus termaktub di Buku II Titel XIX (Pasal 338-Pasal 350). Nyawa memiliki artian yang serupa dengan jiwa. Jiwa sendiri memiliki beberapa arti diantaranya: penyebab hidup, jiwa dan roh (sebagai sebab hidupnya manusia sebagai makhluk), sementara jiwa memiliki artian sebagai roh manusia yang mencakup seluruh kehidupan seorang insan. Sehingga tindak pidana terhadap nyawa dianalogikan dengan tindak pidana yang berkaitan dan berhubungan dengan hidup seorang manusia atau tindakan yang menyebabkan hilangnya hidup/kehidupan manusia disebut sebagai pembunuhan/murder.

Berdasarkan pengaturan dalam KUHP tindak pidana sendiri dapat dibedakan melalui beberapa aspek yaitu: a) Tindak pidana terhadap jiwa manusia; b) Tindak pidana terhadap bayi yang sedang/baru dilahirkan; c) Tindak pidana terhadap jiwa calon anak yang sedang/masih dalam kandungan. Bila dilihat dari perspektif unsur kesengajaan (dolus), bila mengacu pada teori kehendak (wilsiheorie) merupakan suatu kehendak dan kesengajaan hingga terwujudnya suatu perbuatan. Kesengajaan sendiri merupakan kehendak untuk melaksanakan suatu perbuatan yang memenuhi kriteria atau unsur tertentu. Tindak pidana sendiri berdasarkan unsur tersebut dibedakan menjadi tindak pidana yang dilakukan secara sengaja; tindak pidana yang dilakukan dengan sengaja dengan unsur pemberat; keinginan dari yang dibunuh; memberi bantuan atau anjuran orang untuk melakukan tindakan bunuh diri.

Penanganan yang selama ini dilakukan dalam kasus pembunuhan pada umumnya yaitu melalui:

a. Penyelidikan

Penanganan kasus pembunuhan pada tahap penyelidikan dilakukan oleh petugas kepolisian. Tugas yang dimaksud berkaitan dengan penerimaan laporan dan pengaturan, penghentian seseorang yang dicurigai untuk kemudian dilakukan pemeriksaan. Hal ini secara khusus diatur melalui Pasal 1 butir 5 KUHAP yang dimaksud sebagai rangkaian penyelidikan dengan tujuan untuk mencari serta menemukan peristiwa dengan praduga bahwa hasil pencarian tersebut merupakan suatu tindak pidana yang selanjutnya dipergunakan untuk menentukan bisa atau tidak suatu tindak pidana untuk ditindaklanjuti dengan penyidikan menurut tatacara sebagaimana diatur dalam KUHP. Jika ditarik hubungannya dengan teori hukum acara pidana yang diusulkan van Bemmelen, penyelidikan adalah tahap perdana dari 7 (tujuh) tahapan yang ada di dalam

${ }^{30}$ P.A.F Lamintang dan Theo Lamintang, Delik-Delik Khusus Kejahatan Terhadap Nyawa Tubuh dan Kesehatan, (Jakarta:Sinar Grafika, 2012), 1 
hukum acara pidana dengan tujuan untuk mencari dan menemukan kebenaran. $^{31}$

b. Penyidikan

Setelah ditentukan suatu perbuatan yang dilakukan merupakan tindakan pidana pembunuhan, maka selanjutnya polisi akan melakukan penyidikan. Penyidikan dilakukan dengan dasar Pasal 1 butir 2 KUHAP yang didefinisikan sebagai suatu rangkaian tindakan penyidikan dalam hal serta bersesuaian dengan tatacara sebagaimana diatur dalam KUHP yang ditujukan untuk mencari dan mengoleksi bukti yang selanjutnya akan menjadi petunjuk yang menerangkan perihal tindak pidana yang telah terjadi dan untuk menemukan tersangka dari tindak pidana tersebut. Penyidikan adalah suatu kegiatan pemeriksaan pendahuluan atau awal (vooronderzoek) dari rangkaian penegakan hukum yang sudah seharusnya menitik beratkan pencarian atau pengumpulan bukti yang berupa fakta-fakta atas penangkapan serta penggeledahan, pada kondisi yang diperlukan kegiatan tersebut dapat diikuti dengan penahanan tersangka serta penyitaan seluruh barang yang dinilai memiliki kaitan dengan apa yang telah terjadi dan yang sedang diselidiki. ${ }^{32}$

c. Penuntutan

Setelah bukti-bukti kuat terkumpul melalui proses penyidikan kemudian terhadap bukti-bukti tersebut dilimpahkan ke kejaksaan. Setelah dilakukan pelimpahan ke kejaksaan terhadap tindak pidana pembunuhan kemudian dilimpahkan ke pengadilan negeri untuk dilanjutkan ke tahap persidangan. Dalam tahap persidangan, jaksa penuntut umum (JPU) akan melakukan tuntutan terhadap terdakwa berdasarkan kesalahan yang tersangka lakukan. Penuntutan sendiri di Pasal 1 butir 7 KUHAP didefinisikan sebagai tindakan yang dilakukan oleh penuntut umum dengan tujuan untuk melakukan pelimpahan ke pengadilan negeri sesuai dengan kewenangannya bersesuaian dengan tatacara yang diatur melalui undang-undang dengan permintaan untuk kemudian diperiksa serta diputus hakim dalam persidangan di muka pengadilan. Selain itu, Wirjono Prodjodikoro memberikan penekanan pada proses penuntutan yang merupakan kegiatan menuntut seorang terdakwa di hadapan hakim pidana yang dilakukan dengan menyerahkan perkara terdakwa beserta berkas perkaranya ke hakim yang bertugas, yang isinya memohon agar hakim melakukan pemeriksaan, serta selanjutnya dilakukan putusan atas perkara pidana tersebut terhadap terdakwa. ${ }^{33}$

Berikutnya ancaman pidana yang ditujukan kepada anak secara umum sebagaimana ditentukan di KUHP dan Undang-Undang Nomor 11 Tahun 2012 tentang Sistem Peradilan Pidana Anak atau secara lex generalis dan lex specialis

31 Khalimi Elsy, "Pemidanaan Terhadap Anak Yang Melakukan Pembunuhan Dikaitkan Dengan Restorative justice (Studi Putusan Nomor 96PK/PID/2016)," Jurnal Hukum Staatrechts 2, no. 2 (2019): 72-92.

32 Ali Wisnubroto, Praktek Peradilan Pidana (Proses Persidangan Perkara Pidana), (Jakarta: PT. Galaxy Puspa Mega, 2002), 15.

${ }^{33}$ Andi Hamzah , Hukum Acara Pidana Indonesia, (Jakarta: Sinar Grafika, 2009),162. 
ditentukan bahwa anak dijatuhi ketentuan pidana $1 / 2$ (setengah) dari maksimal pidana dewasa, selain itu pada anak tidak diberlakukan pidana seumur hidup dan pidana mati. Dalam penjatuhan sanksi, terdapat klasifikasi sanksi yang didasarkan kepada umur anak saat melakukan tindak pidana yang dibagi menjadi, anak yang memiliki usia biologis 12 (dua belas) tahun hingga 18 (delapan belas) tahun dapat untuk dipidana, namun pada anak dengan memiliki usia biologis 8 (delapan) tahun-12 (dua belas) tahun akan dijatuhi sanksi berupa tindakan. Dalam UU tersebut juga diamanatkan bahwa proses penanganan perkara anak yang berurusan dengan hukum harus dilakukan dengan cara mengutamakan proses diversi seperti yang termaktub dalam Pasal 5 ayat (3). UU SPPA.

\section{Penanganan Pembunuhan Yang Dilakukan Anak Melalui Restorative Justice}

Menegakkan perlindungan hukum kepada anak yang bermasalah dengan hukum bila merujuk pendapat Abdul Hakim Garuda Nusantara, harus dilakukan dengan pendekatan untuk melindungi anak-anak di Indonesia dengan pendekatan yang lebih luas dengan memasukan pertimbangan aspek ekonomi, aspek sosial, dan aspek budaya di dalamnya sehingga perlindungan tersebut dapat memberikan keadilan dan memenuhi hak-hak anak. ${ }^{34}$ Sedangkan berdasarkan pendapat Arif Gosita bahwa perlindungan anak merupakan suatu bentuk usaha yang dilakukan untuk mewujudkan kondisi yang mendukung pelaksanaan hak serta kewajiban setiap anak demi proses tumbuh dan kembangnya yang meliputi aspek fisik, dan mental, serta aspek sosial. ${ }^{35}$ Sehingga pada akhirnya perlindungan terhadap anak dilakukan tidak hanya untuk melindungi fisik si anak, namun mencakup perlindungan yang lebih luas meliputi mental dan sosial yang dilakukan dengan memperhatikan aspek ekonomi, sosial serta budaya dengan harapan anak tidak memiliki hambatan dalam melaksanakan hak serta kewajibannya untuk bertumbuh serta berkembang menjadi sosok manusia yang utuh berdasarkan potensi yang ia miliki dan tidak ada satupun hal yang akan menghambat pertumbuhan dan perkembangan tersebut, termasuk ketika anak berhadapan dengan hukum.

Berhadapan dengan hukum, bagi anak dapat memberikan berbagai pengaruh baik kepada fisik, mental dan sosial anak, terutama apabila permasalahan tersebut diselesaikan melalui jalur formal seperti pengadilan. Keadilan restoratif (restorative justice) hadir untuk menjadi jalur alternatif penyelesaian permasalahan pidana yang dapat dimaknai sebagai jalur penyelesaian non formal. Keadilan restoratif (restorative justice) yang diatur melalui Pasal 24 ayat (1) Kovenan Hak-Hak Sipil dan Politik disebutkan seluruh dan setiap anak memiliki hak untuk memperoleh perlindungan atas dasar asumsi bahwa anak merupakan seseorang dibawah umur yang menjadi landasan hukum yang kuat bagi hakim dalam melakukan penghentian perkara anak. Putusan yang berisi penghentian perkara pidana karena anak dibawah umur dinyatakan sah karena hakim sendiri memiliki kebebasan dalam memberikan

${ }^{34}$ Maidin Gultom, Perlindungan Hukum Terhadap Anak dalam Sistem Peradilan Pidana Anak di Indonesia, (Bandung: PT. Refika Aditama, 2008)

${ }^{35}$ Maidin Gultom 
putusan bila berujuk Pasal 28 ayat (1) Undang-Undang Nomor 4 Tahun 2004 yang memberikan kewenangan bagi hakim untuk menggali dan mengikuti, serta memahami nilai-nilai hukum serta nilai keadilan tumbuh dan berkembang dalam tatanan kemasyarakatan.

Bila merujuk pada hukum internasional, dalam Beijing Rules khususnya dalam Butir 11.1 sendiri, ditetapkan bahwa penggantian proses penegakan hukum dari jalur formal ke dalam jalur non formal melalui keadilan restoratif (restoratif justice) di penanganan perkara anak diperbolehkan untuk dipilih oleh hakim. Keadilan restoratif (restorative justice) menjadi tujuan seorang hakim dalam melakukan penyelesaian perkara anak untuk memaksimalkan perlindungan terhadap masa depan anak yang sesuai dengan asas-asas perlindungan yang diatur dalam Beijing rules, yang: memberikan prioritas terhadap kepentingan terbaik anak; menghindarkan anak dari peradilan pidana (formal); meminimalkan segala bentuk intervensi bagi anak, petugas kepolisian, petugas kejaksaan, dan hakim serta aparat penegak hukum lain hendaklah menggunakan diskresi selama menangani perkara anak; selain itu kriminalisasi serta penjatuhan hukuman anak hendaklah dihindari terkecuali pada kondisi dimana terjadi dampak berupa kerusakan fatal terhadap anak maupun orang lain; dan pemberian bantuan hukum secara cuma-cuma. ${ }^{36}$

Keadilan restoratif (restorative justice) merupakan bentuk respons atas perkembangan sistem peradilan pidana yang memberikan titik berat kepada kebutuhan kontribusi masyarakat serta korban yang termarjinalisasi yang melebur dalam mekanisme sistem peradilan pidana yang dipergunakan di masa saat ini. ${ }^{37}$ Keadilan restoratif (restorative justice) memiliki kemiripan dengan penanganan perkara non penal merupakan pencegahan pidana dengan tidak mempergunakan hukum pidana (prevention without punishment) yang juga merupakan usaha untuk memberikan pengaruh pada cara pandang masyarakat terhadap kejahatan serta pemidanaan dengan sarana media massa. ${ }^{38}$

Kebijakan kriminal melalui pendekatan non penal memiliki korelasi dengan tindakan pencegahan atas terjadinya tindak kejahatan. Sehingga, tujuan dari pengoptimalan sarana non penal berkaitan dengan faktor-faktor kondusif yang menyebabkan timbulnya kejahatan berkaitan dengan masalah-masalah ataupun kondisi-kondisi sosial yang mempengaruhi langgengnya kejahatan baik secara langsung ataupun tidak langsung. ${ }^{39}$ Sehingga dengan demikian jika dinilai dengan dasar kebijakan kriminal penanggulangan kejahatan, pendekatan sarana non penal ini memiliki kedudukan yang sangat strategis serta memiliki peranan vital yang sudah menjadi keharusan untuk dilakukan secara intensif-efektif. ${ }^{40}$

\footnotetext{
${ }^{36}$ L. Yudaningsih, "Penanganan Perkara Anak Melalui Restorative Justice," Jurnal Ilmu Hukum Jambi 5, no. 2 (2014): 432-77.

${ }^{37}$ Yudaningsih.

${ }^{38}$ Beby Suryani , "Pendekatan Integral Penal Policy Dan Non Penal Policy Dalam Penanggulangan Kejahatan Anak", Doktrina: Journal of Law 1, no. 2, (2018): 73

39 Febriyanti Silaen dan Syawal Amry Siregar, "Hubungan Kebijakan Kriminal Dengan Kebijakan Hukum Pidana," Jurnal Darma Agung 28, no. 1 (2020): 8, https://doi.org/10.46930/ojsuda.v28i1.455.

${ }^{40}$ Silaen dan Siregar.
} 
Hakikatnya, peradilan anak memiliki filosofi pencegahan atas sebab dari hadirnya Undang-Undang Nomor 3 Tahun 1997 tentang Pengadilan Anak yang selanjutnya diperbaharui dengan Undang-Undang 11 Tahun 2012 tentang Sistem Peradilan Anak. Peradilan pidana anak secara filosofis menitikberatkan upaya perlindungan serta rehabilitasi anak (emphasizing rehabilitation on youthful offender) yang memaknai anak sebagai entitas yang dilekati dengan seperangkat keterbatasan relatif terhadap orang-orang dewasa. Anak sebagai entitas yang memiliki keterbatasan memerlukan perlindungan negara dan masyarakat secara berkelanjutan hingga anak dinilai mampu untuk bertanggungjawab untuk dirinya sendiri dan tumbuh sesuai dengan potensi yang dimilikinya. ${ }^{41}$ Pada kondisi seorang anak telah melakukan tindak pidana dibutuhkan adanya suatu sistem strategi peradilan pidana khusus yang disesuaikan dengan kondisi yang dimiliki oleh anak, yaitu strategi sistem peradilan pidana yang meminimalkan intervensi sistem peradilan pidana formal selayaknya dikenal oleh khalayak umum.

Diversi sebagai bagian dari pendekatan penanggulangan tindak pidana melalui keadilan restoratif (restorative justice) sejatinya ditujukan untuk mengupayakan perdamaian antara korban dan anak sebagai orang yang melakukan tindak pidana; melakukan penyelesaian perkara anak yang mengambil tempat di luar pengadilan; melindungi kemerdekaan anak dari segala bentuk perampasan; memaksimalkan partisipasi masyarakat; dan menumbuhkan rasa tanggungjawab di dalam diri anak. ${ }^{42}$ Namun demikian dalam pelaksanaannya tetap harus memperhatikan kategori kenakalan yang dilakukan oleh anak dapat untuk dikelompokkan ke dalam tiga kategori, yaitu: ${ }^{43}$

a. Kejahatan ringan

Perbuatan yang dilakukan oleh anak dikatakan sebagai kejahatan ringan meliputi pencurian ringan, penyerangan ringan yang tidak menyebabkan luka, ataupun kerusakan ringan harta benda yang dimiliki.

b. Kejahatan sedang

Perbuatan-perbuatan terkategori sebagai kejahatan sedang merupakan kejahatan dalam bentuk kombinasi antara suluruh kondisi dalam suatu pertimbangan kepantasan suatu perkara untuk diselesaikan dengan sarana diversi ataupun tidak.

c. Kejahatan berat

Perbuatan yang termasuk ke dalam kejahatan berat termanifestasi dala, kasus penyerangan seksual dan penyerangan fisik dengan luka parah sebagai hasil atas perbuatan.

Dalam pelaksanaan diversi terhadap anak sebagai pelaku tindak pidana, tentu terdapat beberapa persyaratan yang hendaknya dipenuhi terlebih dahulu, seperti anak

\footnotetext{
${ }^{41}$ Said, "Perlindungan Hukum Terhadap Anak Dalam Perspektif Hak Asasi Manusia."

${ }^{42}$ I Made Sepud, "Alternatif Penyelesaian Tindak Pidana Narkotika Anak Melalui Diversi”, Jurnal Hukum Prioris 3, no. 3, 2016: 289

${ }^{43}$ Sri Rahayu, "Diversi Sebagai Alternatif Penyelesaian Perkara Tindak Pidana Yang Dilakukan Anak Dalam Perspektif Sistem Peradilan Pidana Anak”, Jurnal Ilmu Hukum, (2015): 134
} 
tersebut baru pertama kali menjadi pelaku atas suatu tindak pidana; memiliki usia yang relatif muda; program diversi yang dilakukan untuk anak telah mendapatkan ijin persetujuan dari orangtua/wali, ataupun anak sebagai pelaku tindak pidana; kategori kejahatan yang dilakukan anak dapat bervariasi dari tingkat kejahatan ringan hingga berat meskipun hanya dalam kasus-kasus tertentu; anak yang berkedudukan sebagai pelaku telah mengaku telah bersalah atas tindak pidana/kejahatan; kontribusi yang diberikan oleh masyarakat berupa dukungan dan masyarakat tidak memiliki keberatan terhadap pengalihan pemeriksaan yang dilakukan; dalam kondisi bila pelaksanaan diversi dinyatakan gagal, maka anak sebagai pelaku diperiksa melalui jalur formal. ${ }^{44}$

Pada kasus pembunuhan tentunya juga dapat dilakukan diversi dengan tetap memenuhi persyaratan yang dinyatakan di atas. Bila pada akhirnya harus dijatuhkan sanksi pidana kepada anak, sanksi tersebut tidak dapat disamakan dengan perlakuan yang diberikan kepada orang dewasa. Bila merujuk pada ketentuan Pasal 71 Undang Undang Nomor 11 Tahun 2012 tentang Sistem Peradilan Pidana Anak terdapat berbagai jenis pidana dan tindakan yang meliputi pidana pokok bagi anak (pidana peringatan, pidana bersyarat: pembinaan di luar atau di dalam lembaga, pelayanan masyarakat maupun dalam bentuk pengawasan, pelatihan kerja, dan penjara); pidana tambahan (perampasan harta yang berasal dari keuntungan yang diperoleh melalui tindak pidana, atau pemenuhan kewajiban adat); apabila anak diancam dengan pidana kumulatif seperti penjara dan denda, pidana yang dimaksud digantikan dengan pelatihan kerja, pidana yang dijatuhkan kepada anak tersebut tidak diperbolehkan untuk melanggar harkat serta martabat anak, ketentuan lanjutan berkenaan dengan jenis pidana dan tindakan pidana anak diatur secara lebih lanjut melui peraturan pemerintah. ${ }^{45}$

Dalam uraian di atas dinyatakan tentang pidana peringatan yang bila mengacu pada ketentuan Pasal 27 UU SPPA, pidana peringatan sendiri merupakan pidana ringan yang tidak membatasi kebebasan anak, selain itu dalam Pasal 73 mengatur bahwa pidana dengan syarat diberikan oleh hakim, apabila pidana tersebut merupakan pidana penjara hanya dijatuhkan paling lama adalah 2 tahun, selain itu dalam melakukan putusan pidana dengan syarat ditentukan adanya persyaratan yang bersifat umum dan khusus. Syarat umum yang dimaksud adalah syarat bahwa anak tidak akan pernah melakukan tindak pidana selama periode pidana dengan syarat tersebut, sedangkan persyaratan khusus yang dimaksud adalah persyaratan yang memberikan larangan kepada anak untuk melakukan hal tertentu sebagaimana ditetapkan oleh hakim melalui putusan pengadilan dengan tetap mempertimbangkan kebebasan yang dimiliki anak. Selain itu, lama pidana dengan syarat khusus yang memiliki durasi lebih lama dibandingkan dengan masa pidana dengan persyaratan

${ }^{44}$ DS. Dewi, Mediasi Penal: Penerapan Restorative Justice Di Pengadilan Anak Indonesia, (Depok:Indie Publishing, 2011), 15.

${ }^{45}$ Saharuddin, "Perlindungan Hukum Terhadap Anak Sebagai Pelaku Tindak Pidana Pembunuhan (Studi Kasus Putusan No: 164/Pid.B/2009/PN.P1)", Jurnal Ilmu Hukum Legal Opinion 2, no. 6, (2014): 5-6 
umum yaitu paling lama 3 tahun; dan selama menjalani pidana dengan syarat tersebut, jaksa penuntut umum memberikan pengawasan, selain itu pembimbing kemasyarakatan memberikan bimbingan agar anak tetap melaksanakan serta memenuhi persyaratan yang telah ditetapkan sebelumnya; selain menjalankan persyaratan yang ditetapkan tersebut anak juga memiliki kewajiban untuk memenuhi wajib belajar 9 tahun.

Peradilan pidana anak bila dimaknai secara lebih luas merupakan sistem peradilan pidana yang disesuaikan untuk menjunjung tinggi hak dan keselamatan serta mengutamakan kesejahteraan fisik serta mental anak. Sehingga pidana penjara seharusnya menjadi ultimum remedium atau upaya hukum terakhir yang dilaksanakan dengan jangka waktu hukuman yang pendek dan hanya diberlakukan pada kasus-kasus yang dianggap menjadi kasus luar biasa bila dilakukan oleh anak. ${ }^{46}$ Apabila anak sebagai pelaku pidana pembunuhan yang telah dilakukan penangkapan oleh polisi, diversi dapat dilakukan oleh petugas kepolisian dalam bentuk diskresi kepada anak dengan tanpa meneruskan perkara tersebut kepada jaksa penuntut umum untuk dilakukan penuntutan. Pada kondisi anak yang tengah berada di tahap pengadilan, hakim memiliki kewenangan untuk melaksanakan peradilan sebagaimana diatur sesuai prosedur dengan mengutamakan kebebasan anak dari dijatuhkannya pidana penjara terhadap anak, apabila anak tersebut terbukti bersalah secara sah dan meyakinkan melakukan tindak pidana pembunuhan sehingga dilakukan penahanan terhadap anak di Lapas Anak, maka petugas Lapas Anak dapat mengambil kebijakan diversi untuk melimpahkan anak ke lembaga sosial atau menjatuhkan sanksi alternatif yang dinilai akan memberikan manfaat maksimal terhadap masa depan anak.

\section{E. PENUTUP}

Penanganan terhadap tindak pidana pembunuhan yang dilakukan oleh anak, pada dasarnya tidak dapat dipersamakan dengan perlakuan yang diberikan kepada orang dewasa. Pada umumnya penanganan perkara pembunuhan dilakukan melalui penyelidikan, penyidikan, dan penuntutan hal ini hanya berlaku bagi orang dewasa sebab dalam anak mempunyai penanganan tersendiri yaitu melalui pendekatan keadilan restoratif (restorative justice). Pendekatan keadilan restoratif yang diambil harus berkonsentrasi pada kebutuhan untuk meningkatkan kontribusi masyarakat dan korban yang saat ini masih termarjinalisasi melalui mekanisme sistem peradilan pidana yang dilakukan pada saat ini. Dalam Undang-Undang No. 11 Tahun 2012 Tentang Sistem Peradilan anak pendekatan yang demikian disebut sebagai diversi. Melalui diversi, anak yang dikategorikan sebagai anak nakal atau anak sebagai pelaku tindak pidana pembunuhan memiliki sedikit perbedaan dalam penjatuhan pidana. Pidana yang dijatuhkan kepada anak yang melakukan tindak pidana pembunuhan merupakan pidana pokok lebih bersifat peringatan yaitu pidana ringan yang tidak membatasi kebebasan anak dan bersifat syarat: pembinaan di luar ataupun

${ }^{46}$ Pramatama dan Sudibya, "Pemidanaan Terhadap Anak Yang Melakukan Tindak Pidana Pembunuhan." 
di dalam lembaga; pelayanan terhadap masyarakat; ataupun pengawasan; pelatihan kerja; dan pidana penjara sebagai upaya terakhir.

\section{DAFTAR PUSTAKA}

Adelina, Theresia, dan A.A. Ngurah Yusa Darmadi. "Perlindungan Hukum Terhadap Anak Sebagai Pelaku Tindak Pidana Penganiayaan (Di Wilayah Hukum Kepolisian Resor Kota Denpasar).” Jurnal Hukum Pidana, (2017):1-15.

A.F Lamintang dan Theo Lamintang, Delik-Delik Khusus Kejahatan Terhadap Nyawa Tubuh dan Kesehatan, Jakarta: Sinar Grafika, 2012.

Ali Wisnubroto, Praktek Peradilan Pidana (Proses Persidangan Perkara Pidana), Jakarta: PT. Galaxy Puspa Mega, 2002.

Ali, Haidir. "Pertanggungjawaban Tindak Pidana Pembunuhan Yang Dilakukan Oleh anak," Dinamika: Jurnal Ilmiah Hukum 5, no. 25, (2019): 1-7.

Andi Hamzah, Hukum Acara Pidana Indonesia, Jakarta: Sinar Grafika, 2009.

Anshari, dan Nina Niken Lestari. "Efektivitas Penerapan Konsep Diversi dan restorative Justice dalam Sistem Peradilan PIdana Anak (Telaah Yuridis Empirik terhadap Kasus Delinkuensi Anak di Pengadilan Negeri Pontianak)." $\begin{array}{llllll}\text { Res Judicata 4, no. } & 1 & \text { (2021): }\end{array}$ https://doi.org/10.5040/9781509934904.ch-021.

Arliman S, Laurensius. "Perlindungan Hukum Bagi Anak Dalam Perspektif Pancasila Dan Bela Negara." UNIFIKASI: Jurnal Ilmu Hukum 05, no. 01 (2018): 58-70.

Astuti, Ana Puji, Anike Nurmalita, dan Rohma Fahlepi Doni. "Teknologi Komunikasi dan Perilaku Remaja." Jurnal Analisa Sosiologi 3, no. 1 (2014): 91-111.

DS. Dewi, Mediasi Penal: Penerapan Restorative Justice Di Pengadilan Anak Indonesia, Depok: Indie Publishing, 2011.

Elsy, Khalimi. "Pemidanaan Terhadap Anak Yang Melakukan Pembunuhan Dikaitkan Dengan Restorative justice (Studi Putusan Nomor 96PK/PID/2016)." Jurnal Hukum Staatrechts 2, no. 2 (2019): 72-92.

Erdianto Effendi, Hukum Pidana Khusus Suatu Pengantar, Bandung: PT. Refika Aditama, 2011.

Fahlevi, Reza. "Aspek Hukum Perlindungan Anak Dalam Prespektif Hukum Nasional." Lex Jurnalica (Journal of Law) 12, no. 3 (2015): 177-91.

Hambali, Azwad Rachmat. "Penerapan Diversi Terhadap Anak Yang Berhadapan dengan Hukum Dalam Sistem Peradilan Pidana (Diversions for Children in Conflict with The Laws in The Criminal Justice System )." Jurnal Ilmu Hukum 13, (2019): 15-30.

Hasibuan, S A. "Kebijakan Pertanggungjawaban Pidana Dalam Rangka Perlindungan Hukum Bagi Anak." Jurnal Hukum Responsif 7, no. 7 (2019): 169-75.

Hutahaean, Bilher, "Penerapan Sanksi Pidana bagi Pelaku Tindak Pidana Anak Kajian Putusan Nomor 50/Pid.B/2009/PN.Btg”, Jurnal Yudisial 6, no.1, (2013).

Juliana, Ria, dan Ridwan Arifin. "Anak dan Kejahatan (Faktor Penyebab dan 
Perlindungan Hukum)." Jurnal Selat 6, no. 2 (2019): 225-34. https://doi.org/10.31629/selat.v6i2.1019.

Maidin Gultom, Perlindungan Hukum Terhadap Anak dalam Sistem Peradilan Pidana Anak di Indonesia, Bandung: PT. Refika Aditama, 2008.

Marlina, Peradilan Pidana Anak di di Indonesia, Bandung: PT. Refika Aditama, 2009.

Nugroho, Dewi Rahmaningsih dan Muhammad Dzikirullah H. Noho,'Kajian Yuridis Kewenangan Pemerintah untuk Memerintahkan Melakukan Merger kepada Entitas Bank pada masa Wabah Covid19 dalam Rezim Perdagangan Internasional", Cakrawala Hukum 22, no. 2, (2020).

Nugraha, Windia, dan Susilo Handoyo. "Penerapan Restorative Justice dalam Penanganan dan Penyelesaian Tindak Pidana Narkotika yang Dilakukan oleh Anak di Kota Balikpapan." De Facto 6, no. 1 (2019): 1-20.

Odala, Violet. "The Spectrum For Child Justice In The International Human Rights Framework: From 'Reclaiming The Delinquent Child' To Restorative Justice." American University International Law Review 27, no. 3 (2012): 543-80.

Pramatama, K D, dan K P Sudibya. "Pemidanaan Terhadap Anak Yang Melakukan Tindak Pidana Pembunuhan.” Kertha Wicara: Journal Ilmu Hukum, (2019):115 .

Prasetyo, Andik. "Perlindungan Hukum Bagi Anak Pelaku Tindak Pidana." Mizan: $\begin{array}{llllll}\text { Jurnal Ilmu Hukum 9, no. } 1 & \text { (2020): } & 51 .\end{array}$ https://doi.org/10.32503/mizan.v9i1.1054.

Pribadi, Dony. "Perlindungan Terhadap Anak Berhadapan Dengan Hukum." Jurnal $\begin{array}{llllll}\text { Hukum } \quad \text { Volkgeist } & 3, & \text { no. } & 1 & \text { (2018): }\end{array}$ https://doi.org/10.35326/volkgeist.v3i1.110.

Puteri, Rizqi Purnama, Muhammad Junaidi dan Zaenal Arifin. "Reorientasi Sanksi Pidana Dalam Pertanggungjawaban Korporasi Di Indonesia", Jurnal USM Law Review 3, no. 1 (2020):103

Rahayu, Sri, "Diversi Sebagai Alternatif Penyelesaian Perkara Tindak Pidana Yang Dilakukan Anak Dalam Perspektif Sistem Peradilan Pidana Anak", Jurnal Ilmu Hukum, (2015).

Riyanto, Agus, "The Existence and Legal Position of the Chief of Police Circular Regarding the Handling of Hate Speech", Journal of the Light of Justice 2, no.23, (2012).

Saharuddin, "Perlindungan Hukum Terhadap Anak Sebagai Pelaku Tindak Pidana Pembunuhan (Studi Kasus Putusan No: 164/Pid.B/2009/PN.Pl)", Jurnal Ilmu Hukum Legal Opinion 6, no.2, (2014).

Saraya, Sitta. "Crime Of Public Information In Indonesia A Comparative Study Punishment System In Foreign Countries Thailand And Japan”, Jurnal Ius Constituendum 4,no. 2 (2019):130

Said, Muhammad Fachri. "Perlindungan Hukum Terhadap Anak Dalam Perspektif Hak Asasi Manusia.” JCH (Jurnal Cendekia Hukum) 4, no. 1 (2018): 141. https://doi.org/10.33760/jch.v4i1.97.

Sepud, I Made, “Alternatif Penyelesaian Tindak Pidana Narkotika Anak Melalui Diversi", Jurnal Hukum Prioris 3, no.3, (2016).

Silaen, Febriyanti, dan Syawal Amry Siregar. "Hubungan Kebijakan Kriminal 
Dengan Kebijakan Hukum Pidana.” Jurnal Darma Agung 28, no. 1 (2020): 8. https://doi.org/10.46930/ojsuda.v28i1.455.

Suryani, Beby, "Pendekatan Integral Penal Policy Dan Non Penal Policy Dalam Penanggulangan Kejahatan Anak", Doktrina: Journal of Law 1, no. 2 (2018). Sudarsono, Kamus Hukum, Jakarta: PT. Rineka Cipta, 2007.

Wagiati Soetodjo, Hukum Pidana Anak, Bandung: PT. Refika Aditama,2006.

Yudaningsih, L. "Penanganan Perkara Anak Melalui Restorative Justice." Jurnal Ilmu Hukum Jambi 5, no. 2 (2014): 432-77. 